\title{
Geology
}

\section{Erosion rates and orogenic-wedge kinematics in Taiwan inferred from fission-track thermochronometry}

\author{
Sean D. Willett, Donald Fisher, Christopher Fuller, Yeh En-Chao and Lu Chia-Yu
}

Geology 2003;31;945-948

doi: $10.1130 / G 19702.1$

\section{Email alerting services}

Subscribe

Permission request click www.gsapubs.org/cgi/alerts to receive free e-mail alerts when new articles cite this article

click www.gsapubs.org/subscriptions/ to subscribe to Geology

click http://www.geosociety.org/pubs/copyrt.htm\#gsa to contact GSA

Copyright not claimed on content prepared wholly by U.S. government employees within scope of their employment. Individual scientists are hereby granted permission, without fees or further requests to GSA, to use a single figure, a single table, and/or a brief paragraph of text in subsequent works and to make unlimited copies of items in GSA's journals for noncommercial use in classrooms to further education and science. This file may not be posted to any Web site, but authors may post the abstracts only of their articles on their own or their organization's Web site providing the posting includes a reference to the article's full citation. GSA provides this and other forums for the presentation of diverse opinions and positions by scientists worldwide, regardless of their race, citizenship, gender, religion, or political viewpoint. Opinions presented in this publication do not reflect official positions of the Society.

\section{Notes}




\title{
Erosion rates and orogenic-wedge kinematics in Taiwan inferred from fission-track thermochronometry
}

\author{
Sean D. Willett Department of Earth and Space Sciences, University of Washington, Seattle, Washington 98125, USA \\ Donald Fisher Department of Geosciences, Pennsylvania State University, University Park, Pennsylvania 16802, USA \\ Christopher Fuller Department of Earth and Space Sciences, University of Washington, Seattle, Washington 98125, USA \\ Yeh En-Chao Department of Geosciences, Pennsylvania State University, University Park, Pennsylvania 16802, USA \\ Lu Chia-Yu Department of Geosciences, National Taiwan University, Taipei 106, Taiwan
}

\section{ABSTRACT}

New apatite and zircon fission-track ages and previously published thermochronometric data are used to evaluate erosion rates and particle paths within the active Taiwan arc-continent collision. We present 20 new apatite fission-track ages and 6 new zircon fission-track ages. Apatite and zircon ages are all reset in the northern and eastern parts of Taiwan, although the region of reset apatite ages is larger. We interpret this pattern as resulting from crustal accretion at the western margin of the orogenic wedge combined with southward propagation of the collision zone. A onedimensional thermal model including erosion provides prediction of the fission-track ages. The distribution of reset ages is best explained with an erosion rate of 4-6 mm/yr. Given a propagation velocity of $60 \mathrm{~mm} / \mathrm{yr}$, this erosion rate implies that nearly $25 \mathrm{~km}$ of material has been eroded from northern Taiwan. The lack of reset ${ }^{40} \mathrm{Ar} /{ }^{39} \mathrm{Ar}$ ages from muscovite and biotite suggests that rockparticle paths have a large horizontal component, a result consistent with an eroding orogenic-wedge model.

Keywords: orogenesis, exhumation, fission-track dating, erosion, heat flow.

\section{INTRODUCTION}

The Taiwan mountain belt has long been recognized as a classic example of arc-continent collision with high erosion rates (Suppe, 1981, 1984). The active collision of the Luzon arc with the passive margin of the Asian mainland has produced a collision zone with widespread seismicity (Wu, 1970), deformation (Suppe, 1980; Fisher et al., 2002), surface uplift (Hsieh and Knuepfer, 2001; Liew et al., 1990; Liew and Lin, 1987), and exhumation (Liu, 1982; Liu et al., 2000, 2001). Taiwan is noted for high erosion rates: the young mountain belt is located at subtropical latitudes and receives heavy monsoonal rains and frequent typhoons; mean annual precipitation in the mountainous regions of Taiwan can exceed $6 \mathrm{~m}$ annually. These high rates of erosion have resulted in high relief and deeply incised topography. Moreover, erosion has exposed metamorphic rocks with late Tertiary greenschistfacies metamorphism in the Central Range (Liou and Ernst, 1984; Stanley et al., 1981; Wang et al., 1998). Thus, collision and erosion have resulted in deformation, metamorphism, and significant exhumation within a few million years.

The obliquity in orientation between the colliding Asian continental margin and the Luzon arc results in systematic southward propagation of the Taiwan collision zone at a rate of 55-90 mm/yr (Suppe, 1984; Byrne and Liu, 2002) (Fig. 1). Thus, although northern Taiwan has undergone collision since at least $4 \mathrm{Ma}$, collision is in early stages in southern Taiwan, and the southern, offshore continuation of the plate boundary is still an oceanic subduction margin with only incipient involvement of continental crust in the collision. Taiwan thus provides an opportunity to study the evolution of deformation, mountain growth, and erosion through substitution of space for time.

The evolution of rates of erosion and exhumation is of particular interest. It has been proposed that erosion rates currently balance tec-

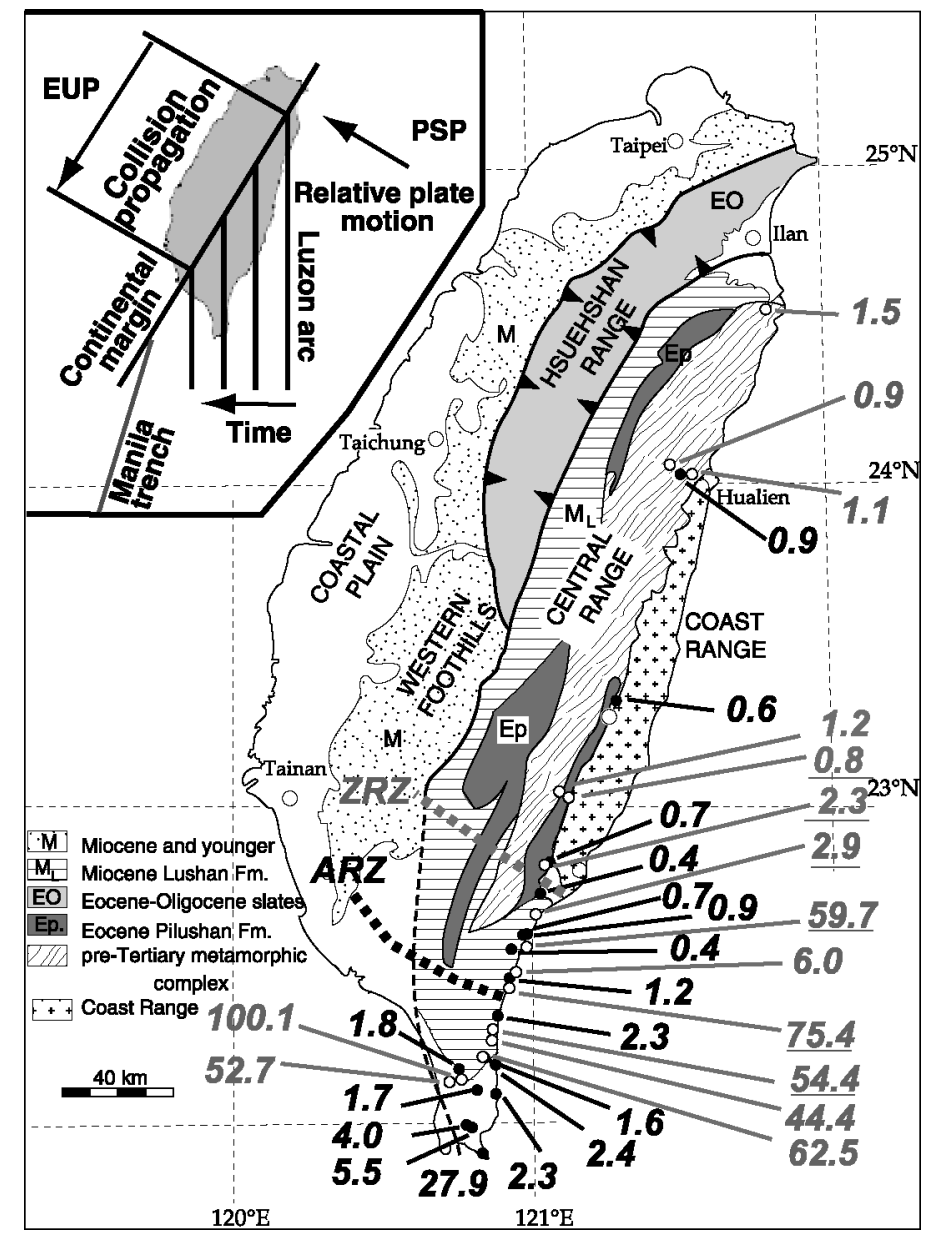

Figure 1. Generalized geologic map of Taiwan with new apatite fission-track ages (black), new zircon fission-track ages (gray, underlined), and zircon fission-track data from Liu et al. (2001) (gray). Apatite ages are pooled ages (in Ma). New zircon ages are pooled ages (in Ma) except $2.9 \mathrm{Ma}$, which is minimum age. Details of new ages are given in Tables DR-1 and DR-2 (see footnote 1 in text). Southern extent of reset zircon age zone is indicated by gray dotted line (ZRZ); southern extent of reset apatite age zone is indicated by black dotted line (ARZ). Inset shows plate configuration for collision between Luzon arc on the Philippine Sea plate (PSP) and Asian passive margin on Eurasian plate (EUP). Position of Luzon arc with progressive time is indicated.

tonic uplift rates, or more precisely, the erosional flux out of the orogen balances the accretionary flux into the orogen, leading to a topographic steady state at the scale of the mountain belt (Deffontaines et al., 1994; Suppe, 1981; Willett and Brandon, 2002). The rates and time of development toward such a steady state and the erosion rates through this evolution are thus important in evaluating the mass balance of the system.

Low-temperature thermochronometry provides a means for deter- 
mining these rates. Cooling rates estimated from thermochronometry provide constraints on the rates of erosional exhumation throughout the mountain belt. In addition, the progressive depth of exhumation seen from south to north in Taiwan should expose rocks whose isotopic systems have been reset at progressively higher temperatures. We exploit this relationship in this paper by reporting new apatite and zircon fission-track ages (Tables DR-1 and DR-2 ${ }^{1}$ ) from a north-south transect along the eastern Central Range of Taiwan that, together with existing zircon fission-track data (Liu et al., 2001) and ${ }^{40} \mathrm{Ar} /{ }^{39} \mathrm{Ar}$ data from hornblende, biotite, muscovite, and K-feldspar (Lo and Onstott, 1995), provide a direct measurement of cooling rates in Taiwan through the process of orogeny and erosion. Combined with thermal models, we also provide an estimate of the erosional exhumation rate and test the models of southward propagation of the Taiwan collision zone.

\section{TECTONIC SETTING-A SOUTHWARD-PROPAGATING COLLISION}

The Luzon arc on the Philippine Sea plate is currently converging with Asia in a northwest direction $\left(\sim 305^{\circ}-310^{\circ}\right)$ at a velocity of $\sim 82$ $\mathrm{km} / \mathrm{m}$.y. (Yu et al., 1997) (Fig. 1, inset). The oceanic crust of the South China Sea has been consumed by subduction at the Manila Trench (Wu, 1970), so that the continental margin of Asia is currently colliding with the Luzon arc in Taiwan. To the south, the remaining South China Sea is closing by a southward "zippering" of this collision zone (Fig. 1, inset). From west to east across northern Taiwan, there is a progressive increase in metamorphic grade and exposed tectonostratigraphic level from the unmetamorphosed Tertiary sedimentary rocks of the Western Foothills thrust belt, through the slates of the Hsuehshan and western Central Ranges, to the pre-Tertiary greenschist-grade schists, gneisses, and marbles of the eastern Central Range. From north to south, the eastern Central Range shows a similar pattern: the pre-Tertiary metamorphic belt is exposed in the north, Eocene slates crop out in southern Taiwan, and weakly cleaved sedimentary rocks form the surface of southernmost Taiwan. These observations suggest a systematically younger system to the south.

\section{THERMOCHRONOMETRY}

Low-temperature thermochronometry provides evidence of progressive exhumation from south to north. The Cretaceous metagranite intrusive complex in northern Taiwan represents the highest grade of metamorphism associated with late Tertiary orogeny (Lo and Onstott, 1995), where microcline ${ }^{40} \mathrm{Ar} /{ }^{39} \mathrm{Ar}$ ages vary from 5 to $2 \mathrm{Ma}$, reflecting rapid recent exhumation. Biotite and muscovite both appear to have undergone minor resetting, indicating that some parts of the complex may have been subjected to temperatures near or even over the closure temperature for biotite $\left(300-350{ }^{\circ} \mathrm{C}\right)$ and muscovite $\left(400{ }^{\circ} \mathrm{C}\right)$.

More extensive spatial coverage is provided by zircon fissiontrack data. Liu et al. $(2000,2001)$ found that zircon fission-track ages from Eocene to Miocene sedimentary rocks in the Central Range were largely reset with minimum ages of 0.9-2.0 Ma. In contrast, zircon fission-track ages from the Western Foothills and southern Taiwan are consistently older than the stratigraphic age of the formation from which they were taken, and thus reflect the age of their predepositional source area. Young minimum ages reflect resetting of the least retentive component of zircons, but more retentive zircons may remain unreset. Most of the samples from the Central Range contain such older zircons. Thus, even these reset ages reflect maximum temperatures of $<300{ }^{\circ} \mathrm{C}$ (Garver and Kamp, 2002). However, reset minimum ages reflect tem-

${ }^{1}$ GSA Data Repository item 2003142, Table DR-1 (apatite fission-track age data) and Table DR-2 (zircon fission-track age data), is available online at www.geosociety.org/pubs/ft2003.htm, or on request from editing@geosociety. org or Documents Secretary, GSA, P.O. Box 9140, Boulder, CO 80301-9140, USA. peratures of at least $180{ }^{\circ} \mathrm{C}$ (Garver et al., 1999), and probably $>240$ ${ }^{\circ} \mathrm{C}$ (Brandon et al., 1998).

The restricted spatial extent of reset minimum zircon fission-track ages indicates limited exhumation of the Western Foothills belt and rocks of southern Taiwan. This interpretation is consistent with the southward propagation of the collision zone that predicts that southern Taiwan would have only recently emerged above sea level and thus become subject to erosion. The Foothills belt represents material most recently accreted into the orogenic wedge and thus has also not been subjected to enough erosional exhumation to expose reset zircons.

The southern extent of the reset-age zone was not well defined by published data, so we obtained and report here six new zircon fissiontrack ages (Fig. 1; Table DR-2 [see footnote 1]) across the north-south transition. The two northernmost ages are completely reset: no individual grain ages are older than the stratigraphic age and pooled ages are 2.3 and $0.8 \mathrm{Ma}$. The three southernmost ages are unreset: mean ages are much older than their Miocene stratigraphic age. The remaining sample appears to be partially reset-only two grain ages are younger than $5 \mathrm{Ma}$-so we have used the mean of these two grain ages $(2.9 \mathrm{Ma})$ as a minimum age, although we recognize that this age reflects only the most easily annealed grains. These data constrain the southern limit of reset zircon fission-track ages to be $\sim 100-120 \mathrm{~km}$ north of the southern tip of Taiwan.

Apatite fission-track ages should show a similar pattern of reset ages, although the propagating-wedge model predicts that the reset-age zone should be larger and therefore extend farther south than for zircon (Willett and Brandon, 2002). We report 17 new apatite fission-track ages (Table DR-1; see footnote 1) in order to test this prediction, with a focus on southern Taiwan (Fig. 1). Apatite was obtained from Tertiary sandstones or the equivalent metasandstones of the slate belt. Apatite yield was generally good; dating was conducted by Donelick Analytical or Dalhousie University (see footnote 1).

Apatite fission-track ages younger than $1 \mathrm{Ma}$ are clearly reset and reflect erosional cooling (Fig. 1). Samples with ages greater than their stratigraphic age are interpreted as unreset. There is an additional group of samples from southern Taiwan with ages between 1.2 and 5.5 Ma. These ages are younger than the corresponding stratigraphic ages, but appear to be too old to reflect exhumation cooling associated with the modern collision. The ages are all from sediments that were likely to have been deposited on young, hot oceanic crust (Chi, 1995), and thus may have been reset by a high geothermal gradient during burial. For the purposes of estimating erosional cooling, these ages are thus treated as effectively unreset and the first reset apatite fission-track ages are found $75 \mathrm{~km}$ north of the southern tip of the island. We note, however, that we cannot exclude the possibility that these ages reflect exhumation cooling that initiated at 2-3 Ma.

\section{THERMAL MODEL}

The appearance of reset ages in progressively higher temperature thermochronometers from south to north in the eastern Central Range presumably reflects the increase in exhumation, which in turn reflects the duration of erosion. If the collision zone is propagating southward at $60 \mathrm{~mm} / \mathrm{yr}$ (Byrne and Liu, 2002), northern Taiwan has been eroding for nearly 5 m.y., whereas southern Taiwan has been subjected to very little erosion. We can quantify this process by constructing a thermal model that includes erosion and use this model to predict fission-track ages. The propagation velocity $\left(v_{\mathrm{p}}\right)$ provides a transformation from space $(x)$ to time $(t), x=v_{\mathrm{p}} t$, so that a one-dimensional, time-dependent model of heat transfer can be compared to observations distributed in space in the orogen-parallel direction.

As a simple analysis of the effects of erosion, we consider an initial steady-state geotherm that is perturbed by erosion at a constant rate, initiated at time zero. Neglecting heat production, the initial geo- 
A

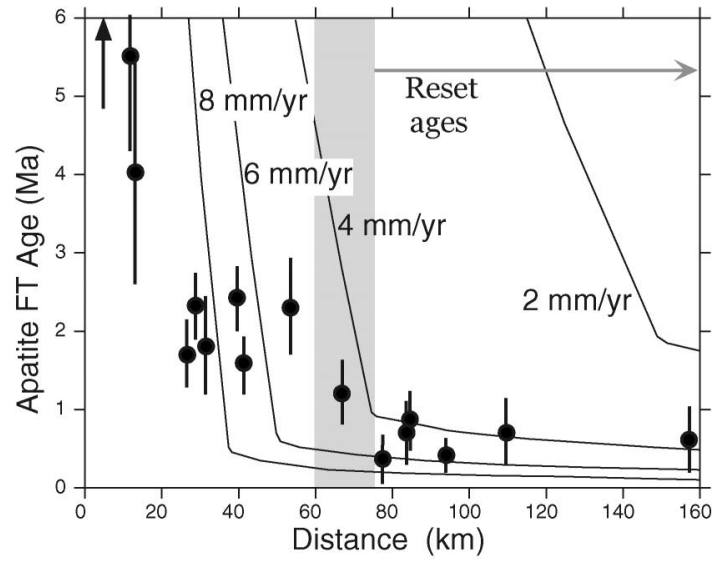

B

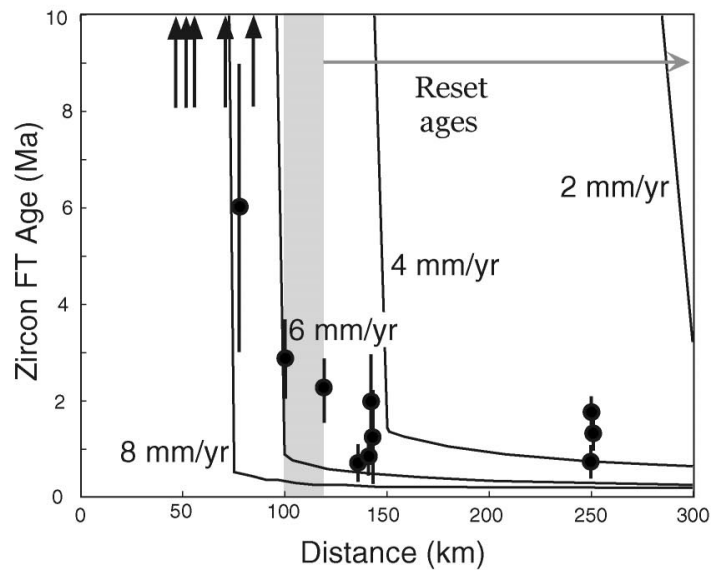

Figure 2. A: Apatite fission-track (FT) ages as function of distance from south end of Taiwan. Reset ages are found north of gray band. Thermal model predicted ages with $(d T / d z)_{\mathrm{i}}=25^{\circ} \mathrm{C} / \mathrm{km}, v_{\mathrm{p}}=60 \mathrm{~mm} / \mathrm{yr}$, and erosion rates as indicated (see text for model details). B: Zircon fissiontrack ages as function of distance from south end of Taiwan. Reset ages are found north of gray band. Model predicted zircon ages as described for $\mathbf{A}$.

therm is linear with a geothermal gradient of $(d T / d z)_{\mathrm{i}}$, where $T=$ temperature and $z=$ depth. Assuming a surface temperature of $10{ }^{\circ} \mathrm{C}$, a thermal diffusivity of $10^{6} \mathrm{~m}^{2} / \mathrm{s}$, and a constant heat flux at the base of the lithosphere, the only free parameters in this model are the erosion rate, $\dot{e}$, and the initial gradient $(d T / d z)_{i}$. Solution of the diffusion equation using a one-dimensional finite-element method provides a prediction of temperature with depth and time. By tracking material paths upward through this temperature field, we obtain temperature histories for rocks reaching the surface as a function of time. These temperature histories are used to predict fission-track ages for apatite and zircon by using the annealing models from Willett (1997) and Brandon et al. (1998), respectively. Transforming the time variable to space gives the results shown in Figure 2.

The model provides no meaningful prediction of age prior to exhumation of reset ages, but it does predict a sharp transition from preorogenic ages to young $(<2 \mathrm{Ma})$ reset ages. Predicted reset ages become progressively younger with time or, equivalently, with distance to the north, reflecting the northward increase of the geothermal gradient by upward heat advection. Reset ages younger than 2 Ma require erosion rates of $>2 \mathrm{~mm} / \mathrm{yr}$, but uncertainty in these ages as well as local thermal effects such as conduction with high-relief topography prohibit determining a stricter constraint on erosion rate directly from the cooling ages. However, the position of the transition from unreset to reset ages is very sensitive to erosion rate. The locations of the reset zone boundaries for apatite and zircon fission-track ages are predicted well by models with erosion rates of $4-5 \mathrm{~mm} / \mathrm{yr}$ and $5-6 \mathrm{~mm} / \mathrm{yr}$, respectively (Fig. 2).

\section{DISCUSSION}

Modeling the progressive exhumation and fission-track ages provides the opportunity to estimate erosion rates for the eastern Central Range and southern Taiwan. An erosion rate of $5 \mathrm{~mm} / \mathrm{yr}$ is consistent with both apatite and zircon fission-track ages (Fig. 2). However, this result depends strongly on two other model parameters, the initial geothermal gradient and the collision-zone propagation velocity. The inferred erosion rate scales almost linearly with these parameters. Fortunately, these parameters can be constrained independently. The unperturbed geothermal gradient along the continental margin to the east (Lee and Cheng, 1986) is between 20 and $25^{\circ} \mathrm{C} / \mathrm{km}$. To the south, the oceanic crust and accretionary wedge have higher geothermal gradients of $40-45^{\circ} \mathrm{C} / \mathrm{km}$ (Chi, 1995). If the initial gradient is as low as $20{ }^{\circ} \mathrm{C} / \mathrm{km}$, our estimate of erosion rate increases to $6.5 \mathrm{~mm} / \mathrm{yr}$. If the initial gradient is $40{ }^{\circ} \mathrm{C} / \mathrm{km}$, the zircon and apatite data are no longer internally consistent, but the inferred erosion rate is between 2 and 3 $\mathrm{mm} / \mathrm{yr}$. With the exception of southernmost Taiwan, the lower gradient of the margin is a more appropriate initial condition.

The collision-zone propagation velocity can be estimated by various means. Suppe (1984) and Byrne and Liu (2002) estimated the propagation velocity from geometric relationships as $90 \mathrm{~mm} / \mathrm{yr}$ and 60 $\mathrm{mm} / \mathrm{yr}$, respectively. Dorsey and Lundberg (1988) noted the progressive subsidence and uplift of basins in the Coast Range and interpreted these motions in terms of uplift of the Central Range at $4 \mathrm{Ma}$ in central Taiwan, consistent with the $60 \mathrm{~mm} / \mathrm{yr}$ propagation velocity used in Figure 2. Deformation in northern Taiwan is estimated to have begun between 7 and 5 Ma (Liu et al., 2000; Suppe, 1984; Teng, 1992), giving a propagation velocity of between 50 and $70 \mathrm{~mm} / \mathrm{yr}$, respectively. If the propagation velocity in our model is as high as $90 \mathrm{~mm} / \mathrm{yr}$, the inferred erosion rate is $7-8 \mathrm{~mm} / \mathrm{yr}$.

We can compare thermochronometers in northern Taiwan to this thermal and erosion model (Fig. 3). Our preferred parameter values, including an erosion rate of $5 \mathrm{~mm} / \mathrm{yr}$, predict that northern Taiwan should have been subject to $20-25 \mathrm{~km}$ of erosion. Assuming onedimensional uplift of a rock column, this amount corresponds to a depth where the initial temperature was $500-600{ }^{\circ} \mathrm{C}$ (Fig. 3). However, thermochronometric ages in northern Taiwan contradict these high temperatures. Unreset hornblende and muscovite ${ }^{40} \mathrm{Ar} /{ }^{39} \mathrm{Ar}$ ages and partially reset biotite ${ }^{40} \mathrm{Ar} /{ }^{39} \mathrm{Ar}$ ages indicate maximum temperatures of $350-400{ }^{\circ} \mathrm{C}$, a range that is consistent with the greenschist-grade metamorphic conditions that affected the metamorphic pre-Tertiary basement rocks of Taiwan (Liou and Ernst, 1984), but not consistent with $20-25 \mathrm{~km}$ of exhumation. One explanation for this discrepancy is that rock motion is not one-dimensional. If material is accreted into the toe of the orogenic wedge in the Western Foothills and moves eastward to be eroded from the Central Range, it is possible to remove $25 \mathrm{~km}$ of rock without exposing that material to high-temperature conditions. With large horizontal motion, rock particles travel along shallow trajectories through the orogenic wedge, undergoing only low depths of burial and low peak temperatures (Barr et al., 1991; Carena et al., 2002; Willett and Brandon, 2002; Batt and Brandon, 2002).

\section{CONCLUSIONS}

Fission-track ages of ca. 1 Ma from Taiwan suggest exhumation rates of a few millimeters per year, but consideration of the spatial pattern of those ages provides a better-resolved estimate of 4-6 mm/ yr. This result provides an important observation of rates of surface erosion in active orogens, but also serves to illustrate the importance of considering the spatial pattern of thermochronometric ages in the context of orogen kinematics. The southward propagation of the arccontinent collision in Taiwan provides the basis for the erosion rate 


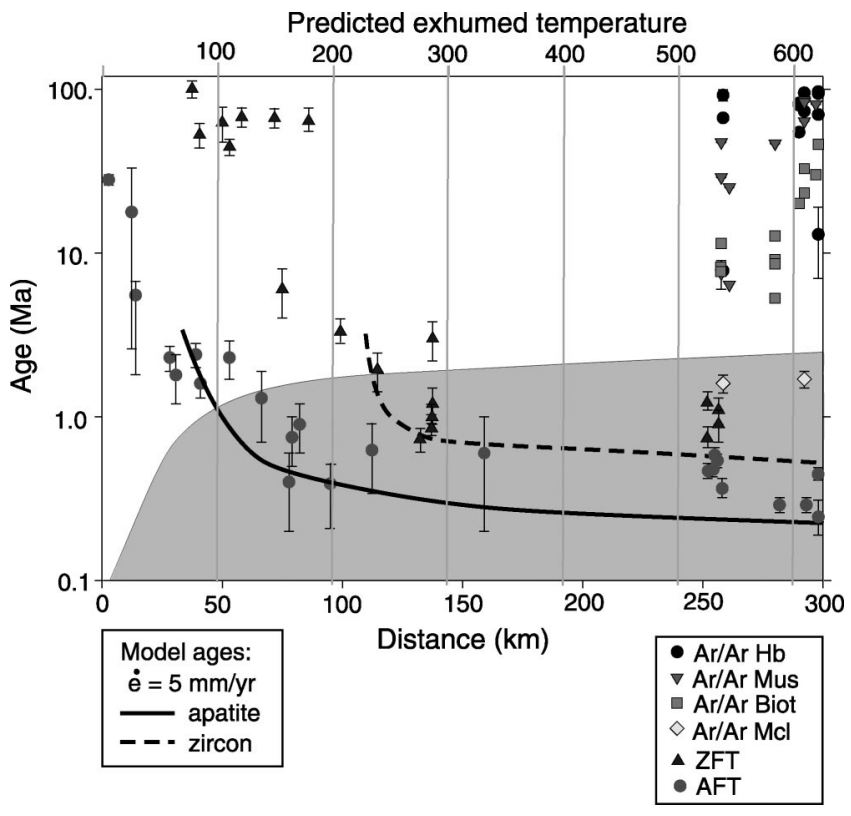

Figure 3. Thermochronometric (apatite and zircon fission track [AFT, ZFT]) ages as function of distance from south end of Taiwan. Plot includes apatite and zircon fission-track data of this paper, apatite fission-track ages of Liu (1982), zircon fissiontrack data of Liu et al. (2001), and ${ }^{40} \mathrm{Ar} /{ }^{39} \mathrm{Ar}$ data for hornblende $(\mathrm{Hb})$, muscovite (Mus), biotite (Biot), and microcline (Mcl) from Lo and Onstott (1995). Solid and dashed curves are predicted fission-track ages from thermal model with erosion rate (è) of $5 \mathrm{~mm} / \mathrm{yr}$. Shaded region represents reset ages based on collisionzone propagation velocity of $60 \mathrm{~mm} / \mathrm{yr}$. Vertical lines indicate distance north from south end of Taiwan for which model predicts exhumation of reset ages of specified closure temperature. Note that ${ }^{40} \mathrm{Ar} /{ }^{39} \mathrm{Ar}$ ages are not reset, contradicting prediction of thermal model.

determination. Consideration of the internal kinematics of the orogenic wedge, including lateral motion of rock, provides a simple explanation for the apparently paradoxical observation that $25 \mathrm{~km}$ of erosion has resulted in $<10 \mathrm{~km}$ of exhumation in northern Taiwan.

\section{REFERENCES CITED}

Barr, T.D., Dahlen, F.A., and McPhail, D.C., 1991, Brittle frictional mountain building: 3. Low-grade metamorphism: Journal of Geophysical Research, v. 96 , p. $10,319-10,338$.

Batt, G.E., and Brandon, M.T., 2002, Lateral thinking: 2-D interpretation of thermochronology in convergent orogenic settings: Tectonophysics, v. 349 , p. $185-201$.

Brandon, M.T., Roden, T.M.K., and Garver, J.I., 1998, Late Cenozoic exhumation of the Cascadia accretionary wedge in the Olympic Mountains, northwest Washington State: Geological Society of America Bulletin, v. 110 , p. $985-1009$.

Byrne, T., and Liu, C.S., 2002, Preface: Introduction to the geology and geophysics of Taiwan, in Byrne, T., and Liu, C.S., eds., Geology and geophysics of an arc-continent collision, Taiwan: Geological Society of America Special Paper 358, p. v-viii.

Carena, S., Suppe, J., and Kao, H., 2002, Active detachment of Taiwan illuminated by small earthquakes and its control of first-order topography: Geology, v. 30, p. 935-938.

Chi, W.C., 1995, Distribution of the bottom-simulating reflector in the offshore Taiwan collision zone: Implications for fluid migration [M.S. thesis]: San Jose, California, San Jose State University, 46 p.

Deffontaines, B., Lee, J., Angelier, J., Carvalho, J., and Rudant, J.-P., 1994, New geomorphic data on the Taiwan orogen: A multisource approach: Journal of Geophysical Research, v. 99, p. 20,243-20,266.

Dorsey, R.J., and Lundberg, N., 1988, Lithofacies analysis and basin reconstruc- tion of the Plio-Pleistocene collisional basin, Coastal Range of eastern Taiwan: Acta Geologica Taiwanica, v. 26, p. 57-132.

Fisher, D.M., Lu, C.Y., and Chu, H.T., 2002, Taiwan Slate Belt: Insights into the ductile interior of an arc-continent collision, in Byrne, T., and Liu, C.S., eds., Geology and geophysics of an arc-continent collision, Taiwan: Geological Society of America Special Paper 358, p. 93-106.

Garver, J.I., and Kamp, P.J.J., 2002, Integration of zircon color and zircon fission track zonation patterns in orogenic belts: Application of the Southern Alps, New Zealand, in Low temperature thermochronology: From tectonics to landscape evolution: Tectonophysics, v. 349, Special Issue, p. 203-219.

Garver, J.I., Brandon, M.T., Roden-Tice, M., and Kamp, P.J.J., 1999, Erosional denudation determined by fission-track ages of detrital apatite and zircon, in Ring, U., et al., eds., Exhumation processes: Normal faulting, ductile flow, and erosion: Geological Society of London Special Publication 154, p. $283-304$.

Hsieh, M.L., and Knuepfer, P.L.K., 2001, Middle-late Holocene river terraces in the Erhjen River Basin, southwestern Taiwan-Implications of river response to climate change and active tectonic uplift: Geomorphology, v. 38 , p. 337-372.

Lee, C.R., and Cheng, W.T., 1986, Preliminary heat flow measurements in Taiwan, in Proceedings, Fourth Circum-Pacific Energy and Mineral Resources Conference: Singapore.

Liew, P.M., and Lin, C.F., 1987, Holocene tectonic activity of the Hengchun Peninsula as evidenced by the deformation of marine terraces: Geological Society of China Memoir 9, p. 241-259.

Liew, P.M., Hsieh, M.L., and Lai, C.K., 1990, Tectonic significance of Holocene marine terraces in the Coastal Range, eastern Taiwan: Tectonophysics, v. 183 , p. $121-127$.

Liou, J.G., and Ernst, W.G., 1984, Summary of Phanerozoic metamorphism in Taiwan: Geological Society of China Memoir 6, p. 133-152.

Liu, T.K., 1982, Tectonic implication of fission-track ages from the Central Range, Taiwan: Geological Society of China Proceedings, v. 25, p. 22-37.

Liu, T.K., Chen, Y.G., Chen, W.S., and Jiang, S.H., 2000, Rates of cooling and denudation of the early Penglai orogeny, Taiwan, as assessed by fissiontrack constraints: Tectonophysics, v. 320, p. 69-82.

Liu, T.K., Hseih, S., Chen, Y.-G., and Chen, W.-S., 2001, Thermo-kinematic evolution of the Taiwan oblique-collision mountain belt as revealed by zircon fission track dating: Earth and Planetary Science Letters, v. 186, p. $45-56$.

Lo, C.H., and Onstott, T.C., 1995, Rejuvenation of K-Ar systems for minerals in the Taiwan Mountain belt: Earth and Planetary Science Letters, v. 131, p. $71-98$.

Stanley, R.S., Hill, L.B., Chang, H.C., and Hu, H.N., 1981, A transect through the metamorphic core of the central mountains, southern Taiwan: Geological Society of China Memoir 4, p. 443-473.

Suppe, J., 1980, A retrodeformable cross section of northern Taiwan: Geological Society of China Proceedings, v. 23, p. 46-55.

Suppe, J., 1981, Mechanics of mountain-building and metamorphism in Taiwan: Geological Society of China Memoir 4, p. 67-89.

Suppe, J., 1984, Kinematics of arc-continent collision, flipping of subduction, and back-arc spreading near Taiwan: Geological Society of China Memoir 6, p. 21-33.

Teng, L.S., 1992, Geotectonic evolution of Tertiary continental margin basins of Taiwan: Petrology and Geology of Taiwan, v. 27, p. 1-19.

Wang, P.L., Lin, L.H., and Lo, C.H., $1998,{ }^{40} \mathrm{Ar} /{ }^{39} \mathrm{Ar}$ dating of mylonitization in the Tananao schist, eastern Taiwan: Geological Society of China Journal, v. 41 , p. $159-183$.

Willett, S.D., 1997, Inverse modeling of annealing of fission tracks in apatite: 1. A controlled random search method: American Journal of Science, v. 297 , p. $939-969$.

Willett, S.D., and Brandon, M.T., 2002, On steady states in mountain belts: Geology, v. 30, p. 175-178.

Wu, FT., 1970, Focal mechanisms and tectonics in the vicinity of Taiwan: Seismological Society of America Bulletin, v. 60, p. 2045-2056.

Yu, S.-B., Chen, H.-Y., and Kuo, L.-C., 1997, Velocity of GPS stations in the Taiwan area: Tectonophysics, v. 274, p. 41-59.

Manuscript received 2 April 2003

Revised manuscript received 10 July 2003

Manuscript accepted 15 July 2003

Printed in USA 